\title{
APPLICATION OF VEGETATIVE BUFFER STRIPS UNDER NATURAL RAINFALL TO CONSERVE SOIL AND WATER
}

\author{
ATAOLLAH KAVIAN*, IMAN SALEH, MAHMOUD HABIBNEJAD, ZEINAB JAFARIAN
}

Sari Agricultural Sciences and Natural Resources University (SANRU), Sari, Mazandaran, Iran

KAVIAN, A. - SALEH, I. - HABIBNEJAD, M. - JAFARIAN, Z.: Application of vegetative buffer strips under natural rainfall to conserve soil and water. Agriculture (Pol'nohospodárstvo), vol. 64, 2018, no. 1, pp. $17-27$.

\begin{abstract}
Soil erosion is one of the most serious environmental issues in the world. The use of vegetative buffer strips is an effective strategy to reduce surface water pollutions as well as soil erosion. The present research has been conducted with aim to study the efficiency of buffer strips in runoff volume and sediment control using experimental plots. In this regard, twelve experimental plots with the dimensions of $1 \mathrm{~m} \times 10 \mathrm{~m}$ were provided, and runoff samples were collected monthly to measure runoff volume and sediment. Vetiver grass and tall fescue were used as the plant species of the studied vegetative buffer strips. It was found that, vegetative buffer strips reduced the runoff volume up to $97 \%$ and sediment concentration up to $96 \%$. Vetiver grass showed a high efficiency in runoff and sediment control; but, the maximum efficiency is achieved when this species is used along with a plant similar to the tall fescue in terms of density and uniformity. Also, periodic cutting the plants and cleaning the buffer strips can be considered as effective strategies to prevent vegetative buffer strips acting as the source of sediment.
\end{abstract}

Key words: sediment, vetiver grass, tall fescue, runoff volume, Sari

Soil erosion is one of the most serious environmental issues around the world. This problem occurs by soil exposure due to loss of vegetation cover which causes soil and water capacity reduction, pollution and eutrophication of water bodies (Morgan 1995; Hay et al. 2006; Keesstra et al. 2016; Kavian et al. 2017; Rodrigo-Comino et al. 2018). The use of vegetative buffer strips is a measure to deal with the mentioned issues (Yuan et al. 2009). Vegetative buffer strips include various plants such as grass, tree and shrub installed at the downstream of erodible and agricultural lands as well as river banks (Dabney 2003; Saleh et al. 2018). The mentioned strips are generally used for surface flows, sediment trapping, nutrient filtering and providing appropriate aquatic habitat (Yuan et al. 2009).
Vetiver grass (Vetivera zizanioides). Vetiver grass is widely used as a bioengineering technique to stabilize slopes, phytoremediation of polluted land and water, and many other environmental conservation measures (Shooshtarian \& Tehranifar 2011). This plant is a fast-growing species with a height of $50-150 \mathrm{~cm}$ and an extent of $30 \mathrm{~cm}$. The roots of vetiver grass are so branched and bulky those which penetrate up to the depths of $2-4 \mathrm{~m}$ in the soil; so, it is very effective for soil and water conservation (Iranian Association for Vetiver Promotion 2008). Vetiver grass is compatible with different climatic conditions, such as flooding, longterm drought, and temperatures in the range of 14 to $55^{\circ} \mathrm{C}$. Also, this plant is capable to re-grow after environmental stresses such as salinity, drought

Ataollah Kavian, Associate Professor, (*Corresponding author), P.B. 737, Department of Watershed Management, Faculty of Natural Resources, $9^{\text {th }} \mathrm{km}$ of Neka Road, Sari, Iran. E-mail: a.kavian@sanru.ac.ir; ataollah.kavian@gmail.com Iman Saleh, PhD., P.C. 7196745547, Roz Building, Farmandari St., Hesabi Blvd., Shiraz, Iran. E-mail: salehiman61@gmail.com Mahmoud Hebibnejad, Professor, P.B. 737, $9^{\text {th }} \mathrm{km}$ of Neka Road, Sari, Iran. E-mail: roshanbah@yahoo.com Zeinab Jafarian, Associate Professor, P.B. 737, 9th km of Neka Road, Sari, Iran. E-mail: Z.Jafarian@sanru.ac.ir 
and etc. Tolerance of a wide range of soil acidity is another characteristic of vetiver grass as well as resistance to the herbicides and pesticides.

Tall fescue (Festuca arundinacea). This plant species is able to increase the soil permeability and create the sheet flow due to the proper density and fast growth. So, the tall fescue can be considered as a suitable plant to be used in vegetative buffer strips.

Many studies have been conducted on the effect of vegetative buffer strips on runoff quality and quantity control (Norris 1993; Delgado et al. 1995; Lee et al. 2003; Patty et al. 1997; Golabi et al. 2005; Borina et al. 2005; Hay et al. 2006; Mankin et al. 2007; Duchemin \& Hogue 2009; Borin et al. 2010; Milan et al. 2014). Some researchers have attempted to give a guideline for using the vegetative buffer strips for the water quality control. They believed that, the proximity of vegetative buffer strips to the source of contaminations may play an important role in their efficiency (Norris 1993). Hay et al. (2006) conducted an experimental study to evaluation of the impacts of the vegetative buffer strips on removing some pollutants generated by irrigated lands and rangelands, filter strips may not have high efficiency, because of high runoff volume, high slope and channelized flow. Investigation of hydraulic characteristics of runoff and sediment production in steep plots covered by grass has shown that, the plot covered by grass has less runoff and sediment by $14-25 \%$ and $81-95 \%$ respectively, than the plot control (Pan \& Shangguan 2006). Lambrechts et al. 2014 studied the effect of plant and its morphology on the efficiency of vegetative buffer strips using experimental flume. They indicated the high sediment trapping potential of vegetative buffer strips after two months growing. According to the reports of the researcher above, plant growth increases sediment trapping by the vegetative buffer strips. Patty et al. (1997) conducted a study and stated that the grass strips with lengths of 6,12 and $18 \mathrm{~m}$ were reduced the runoff volume by $87-100 \%$ and suspended solids by $44-100 \%$. Lee et al. (2003) believed that a combination of various plants can enhance the effectiveness of the vegetative buffer strips for runoff pollution removal. Evaluation of the effect of a grass-tree system on filtering the runoff generated by a corn field fertilised by manure indicated that a grass strip can remove the runoff volume by $40 \%$, suspended solids by $87 \%$, total phosphorous by $64 \%$ and nitrate up to about $33 \%$; while, the grasstree strips reduced the runoff volume by $35 \%$, suspended solids by $85 \%$, total phosphorous by $85 \%$ and nitrate up to about 30\% (Duchemin \& Hogue 2009). After reviewing the data obtained from the studies on the performance of vegetative buffer strips in Italy, Borin et al. (2010) reported that the young buffer strips can reduce the phosphorous loss up to about $50 \%$, nitrogen loss up to $44 \%$ and runoff volume by $33 \%$ as compared to the bare areas. Wakida et al. (2014) found a high correlation between the concentrations of suspended solids, phosphorus, chemical oxygen demand and turbidity, but not for total nitrogen in the Tijuana city. Campo-Bescos et al. (2015) believed that the installation of intense vegetative buffers in irrigated lands can improve the environmental conservation. However, it should not be considered as a main strategy; but also, it should be used as a supplementary pollution control approach along with other measures outside the field.

As many studies showed, the effectiveness of the vegetative buffer strips in runoff reduction and sediment removal; however, the impact of plant species on the efficiency of buffer strips has been less studied on plot scale.

The present study evaluated the impact of vetiver grass (Vetivera zizanioides) and native tall fescue (Festuca arundinacea) in runoff volume reduction and sediment removal using experimental plots of Sari (Iran) and the combination of these species on the efficiency of vegetative buffer strips in runoff volume reduction and sediment removal using experimental plots.

\section{MATERIAL AND METHODS}

\section{Site description}

The study site includes a part of rain-fed croplands of Miandorood (Mazandaran, Iran) where the wheat is grown. The study area is located at the eastern longitude of $53^{\circ} 10^{\prime}$ and northern latitude of $36^{\circ}$ $33^{\prime}$ at the northern hemisphere (Figure 1).

Table 1 shows some characteristics of the studied site based on Dasht-e-Naz station weather data (Sadeghi Ravesh 2011). 
$\mathrm{T}$ a

Characteristics of the studied site

\begin{tabular}{|c|c|c|c|c|c|c|c|}
\hline Land use & $\begin{array}{c}\text { Soil texture } \\
\text { classification } \\
\text { (USDA) }\end{array}$ & $\begin{array}{c}\text { Soil } \\
\text { classification } \\
\text { (USCS) }\end{array}$ & Soil type & $\begin{array}{c}\text { Elevation } \\
\text { from sea } \\
\text { level }[\mathrm{m}]\end{array}$ & Slope [\%] & $\begin{array}{c}\text { Mean annual } \\
\text { temperature } \\
{\left[{ }^{\circ} \mathrm{C}\right]}\end{array}$ & $\begin{array}{c}\text { Relative } \\
\text { humidity [\%] }\end{array}$ \\
\hline $\begin{array}{c}\text { Cropland } \\
\text { (wheat) }\end{array}$ & Clay-loam & $\mathrm{OH}$ & Non-saline & 23 & 15 & 17 & 77 \\
\hline
\end{tabular}

\section{Experimental design}

The present study includes a one-year experiment. Twelve experimental plots with the dimensions of $1 \mathrm{~m} \times 10 \mathrm{~m}$ and the slope of $15 \%$ were provided as randomized complete block design; so that, there were four treatments including vetiver grass, native tall fescue, combination of vetiver grass and native tall fescue, and bare (control) plots with three replications.

In the present study, experimental plots used those which were isolated with the intervals of $10 \mathrm{~cm}$ deep in the soil using galvanized sheets (Lee et al. 1999; Kelarestaghi et al. 2008) (Figure 2). Also, a path was created at the downslope of each plot to drain the outflow into a $120 \mathrm{~L}$ tank. The studied plants cultivated in late January and divided into two parts with the lengths of $3 \mathrm{~m}$ and $7 \mathrm{~m}$. In $3 \mathrm{~m}$ part, the studied plant species were cultivated and the remaining $7 \mathrm{~m}$ was left as bare. The vegetation cover of the studied plants also was monitored during the experiment period (Table 2).

\section{Runoff sampling}

The runoff samples were taken from the rainfall water collected by tanks existing at downslope of each plot monthly since February 2015 until Jan-

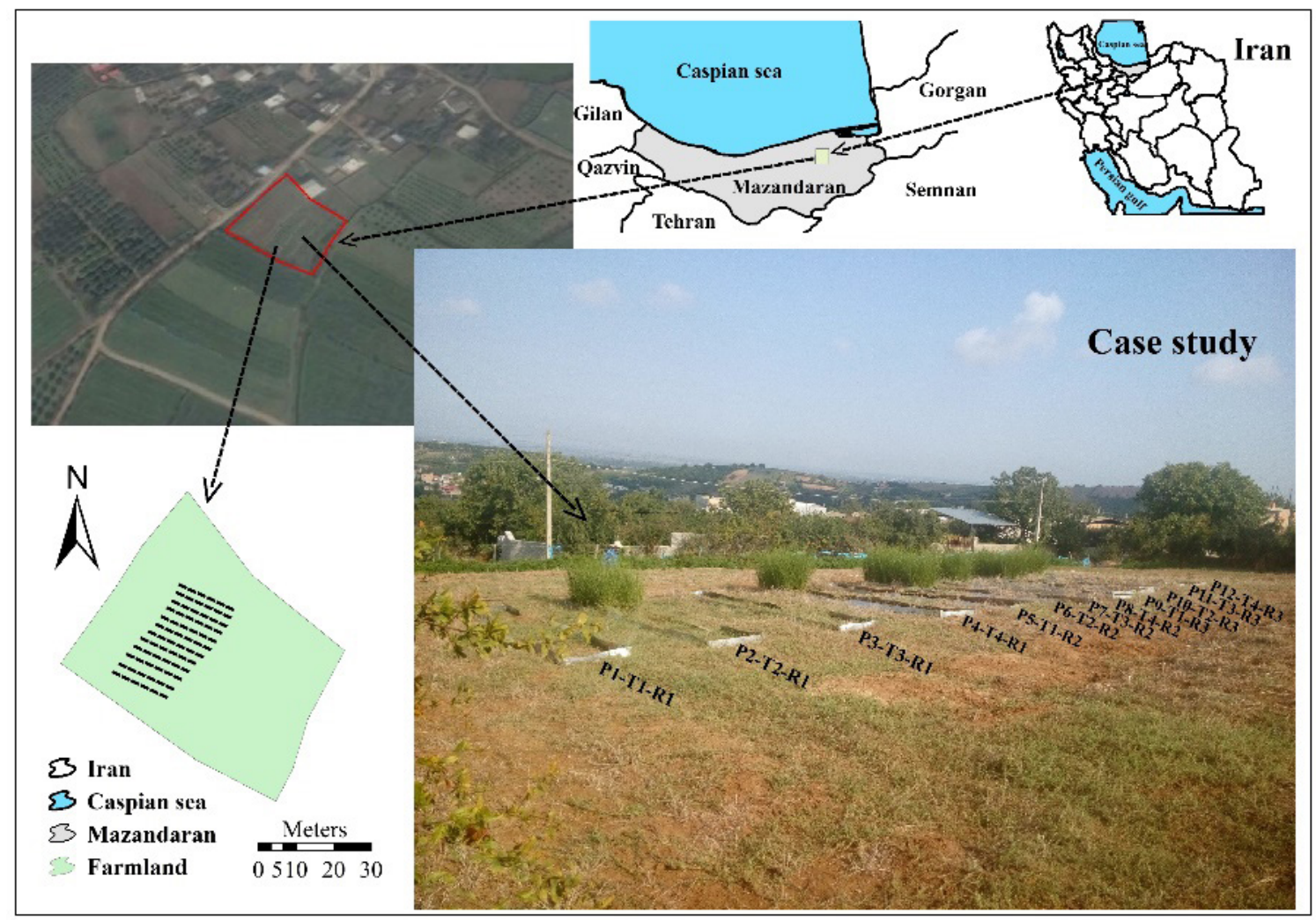

Figure 1. Location of the study area 
$\mathrm{T}$ a

The vegetation cover of the studied plants during the experiment period

\begin{tabular}{|c|c|c|c|c|c|c|c|c|c|c|c|c|}
\hline \multirow{2}{*}{$\begin{array}{c}\text { Plant } \\
\text { species }\end{array}$} & $\begin{array}{c}\text { Feb } \\
2015\end{array}$ & $\begin{array}{c}\text { Mar } \\
2015\end{array}$ & $\begin{array}{c}\text { Apr } \\
2015\end{array}$ & $\begin{array}{c}\text { May } \\
2015\end{array}$ & $\begin{array}{c}\text { Jun } \\
2015\end{array}$ & $\begin{array}{c}\text { Jul } \\
2015\end{array}$ & $\begin{array}{c}\text { Aug } \\
2015\end{array}$ & $\begin{array}{c}\text { Sep } \\
2015\end{array}$ & $\begin{array}{c}\text { Oct } \\
2015\end{array}$ & $\begin{array}{c}\text { Nov } \\
2015\end{array}$ & $\begin{array}{c}\text { Dec } \\
2015\end{array}$ & $\begin{array}{c}\text { Jan } \\
2016\end{array}$ \\
\hline & \multicolumn{10}{|c|}{ Vegetation cover [\%] } \\
$\begin{array}{c}\text { Tall } \\
\text { fescue } \\
\begin{array}{c}\text { Vetiver } \\
\text { grass }\end{array}\end{array}$ & 60 & 65 & 65 & 60 & 40 & 30 & 30 & 30 & 25 & 25 & 25 & 25 \\
\hline
\end{tabular}

uary 2016. Before measuring the outflow volume, a 1.5 L sample was taken in order to determine sediment concentration (Lee et al. 1999; Kavian et al. 2014). Also, the amount of precipitation was measured during the experiment period using a storage rain-gauge (Table 3).

\section{Pollutants measurement}

Nitrate and phosphate concentrations were measured in the laboratory of Regional Water Office of Sari (Mazandaran, Iran). In order to measure the sediment concentration of the water samples, the samples were firstly weighted and then, were dried under temperature of $105^{\circ} \mathrm{C}$ in an oven for 24 hours. Finally, the samples were weighted again to obtain the weight of dry sediment. Equation (1) calculates the amount of total suspended solids of water samples (Lee et al. 1999; Mohammadi \& Kavian 2015).

$$
\operatorname{TSS}=\frac{\mathrm{M}}{\mathrm{V}}
$$

where: $\mathrm{M}$ is the weight of dry solids $[\mathrm{mg}]$ and $\mathrm{V}$ is the volume of water sample [L].

Determination of the efficiency of the vegetative buffer strips

Efficiency of the studied vegetative buffer strips in runoff volume reduction and sediment removal calculated using Equation (2) (Lee et al. 1999).

Effectiveness $\left(\mathrm{T}_{1}\right)=\left(1-\frac{\mathrm{P}_{1}}{\mathrm{P}_{1}}\right) \times 100$ Equation $(2)$
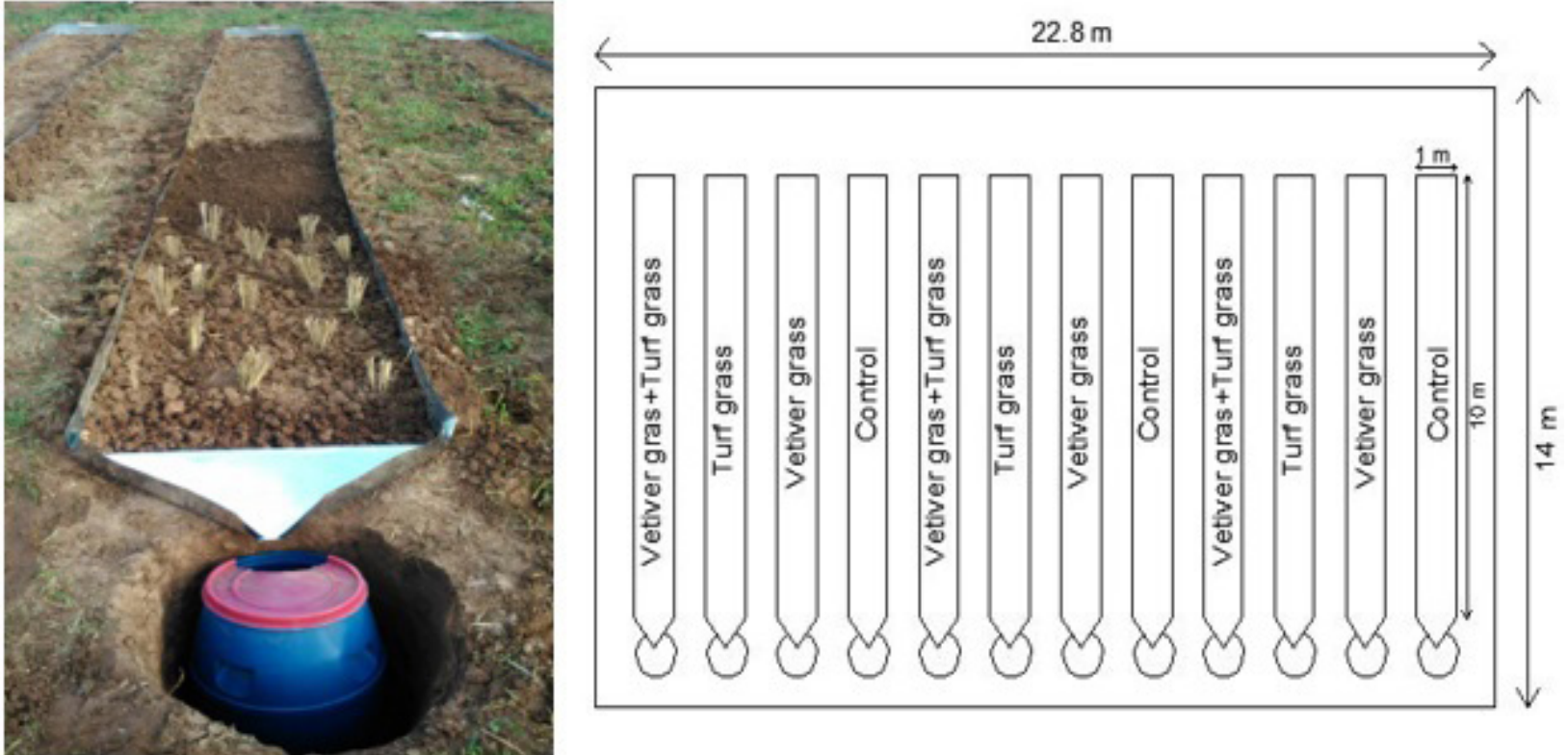

Figure 2. Installation of the experimental plots 
where: $\mathrm{T}_{i}$ is the efficiency of treatment (i) [\%], $\mathrm{P}_{\mathrm{i}}$ is the value of sediment concentration (runoff volume) in the runoff sample of the treatment (i) and $\mathrm{P}_{1}$ is the value of sediment concentration (runoff volume) in the runoff sample of the control plot.

\section{Statistical analysis}

First, a data base was provided in Excel software (2013) and then, the normality test for the data was carried out using Kolmogorov-Smirnov approach. Finally, comparison of means was con

ducted using SPSS software Version 18 to compare the performance of different treatments sediment removal and runoff volume reduction (SPSS Ink 2009).

\section{RESULTS}

\section{Runoff volume}

According to the results the treatment of tall fescue has the minimum amount of runoff volume flowing out of the experimental plots in the first and second months of the experiment with a significant difference $(P=0.01)$ compared to the other studied treatments. It is due to the fast growth of tall fescue and higher density compared to the vetiver grass during the mentioned period. The treatment of vetiver grass-tall fescue showed the least outflow volume since the fourth month until the $10^{\text {th }}$ month. This performance is due to the growth of vetiver grass and higher soil permeability caused by the vetiver roots in the mentioned period. After the $10^{\text {th }}$ month when the density of tall fescue was reduced due to climatic conditions and grazing, the treatment of vetiver grass-tall fescue had the minimum amount of runoff volume along with the treatment of the vetiver grass (Figure 3 ).

Figure 4 represents the best performance of runoff volume reduction for the treatment of tall fescue in the first $(66 \%)$ and second $(76 \%)$ months. The treatment of vetiver grass-tall fescue showed the highest efficiency compared to the other treatments

$\mathrm{T}$ a

The amount of precipitation during the experiment period

\begin{tabular}{|c|c|c|c|c|c|c|c|c|c|c|c|}
\hline Feb & Mar & Apr & May & Jun & Jul & Aug & Sep & Oct & Nov & Dec & Jan \\
2015 & 2015 & 2015 & 2015 & 2015 & 2015 & 2015 & 2015 & 2015 & 2015 & 2015 & 2016 \\
\hline \multicolumn{10}{|c|}{ Amount of precipitation [mm] } \\
\hline 19.7 & 23 & 118.8 & 15 & 5.4 & 3.5 & 83.8 & 3.6 & 112.6 & 112.5 & 100.4 & 55.3 \\
\hline
\end{tabular}

$\mathrm{T}$ a b 1 e 4

Comparison of the means of sediment concentration in the four studied treatments during the experiments

\begin{tabular}{|c|c|c|c|c|c|c|c|c|c|c|c|c|c|}
\hline \multirow{2}{*}{ Treatment } & $\begin{array}{c}\text { Feb } \\
2015\end{array}$ & $\begin{array}{c}\text { Mar } \\
2015\end{array}$ & $\begin{array}{c}\text { Apr } \\
2015\end{array}$ & $\begin{array}{c}\text { May } \\
2015\end{array}$ & $\begin{array}{c}\text { Jun } \\
2015\end{array}$ & $\begin{array}{c}\text { Jul } \\
2015\end{array}$ & $\begin{array}{c}\text { Aug } \\
2015\end{array}$ & $\begin{array}{c}\text { Sep } \\
2015\end{array}$ & $\begin{array}{c}\text { Oct } \\
2015\end{array}$ & $\begin{array}{c}\text { Nov } \\
2015\end{array}$ & $\begin{array}{c}\text { Dec } \\
2015\end{array}$ & $\begin{array}{c}\text { Jan } \\
2016\end{array}$ \\
\hline & \multicolumn{10}{|c|}{ Sediment concentration $[\mathrm{g} / 1]^{*}$} \\
\hline $\begin{array}{c}\text { Control } \\
\begin{array}{c}\text { Vetiver } \\
\text { grass }\end{array}\end{array}$ & $56.35^{\mathrm{b}}$ & $53.61^{\mathrm{c}}$ & $42.51^{\mathrm{c}}$ & $60.55^{\mathrm{d}}$ & $86.29^{\mathrm{c}}$ & $97.30^{\mathrm{c}}$ & $54.13^{\mathrm{d}}$ & $95.00^{\mathrm{d}}$ & $44.83^{\mathrm{c}}$ & $49.07^{\mathrm{d}}$ & $53.63^{\mathrm{d}}$ & $56.97^{\mathrm{c}}$ \\
$\begin{array}{c}\text { Tall fescue } \\
\begin{array}{c}\text { Vetiver } \\
\text { grass-tall } \\
\text { fescue }\end{array}\end{array}$ & $20.29^{\mathrm{a}}$ & $5.90^{\mathrm{a}}$ & $5.10^{\mathrm{ab}}$ & $9.69^{\mathrm{c}}$ & $18.12^{\mathrm{b}}$ & $27.24^{\mathrm{b}}$ & $21.65^{\mathrm{c}}$ & $37.05^{\mathrm{c}}$ & $21.97^{\mathrm{b}}$ & $27.48^{\mathrm{c}}$ & $30.03^{\mathrm{c}}$ & $34.18^{\mathrm{b}}$ \\
\hline
\end{tabular}

*Means followed by the same letter do not differ statistically 

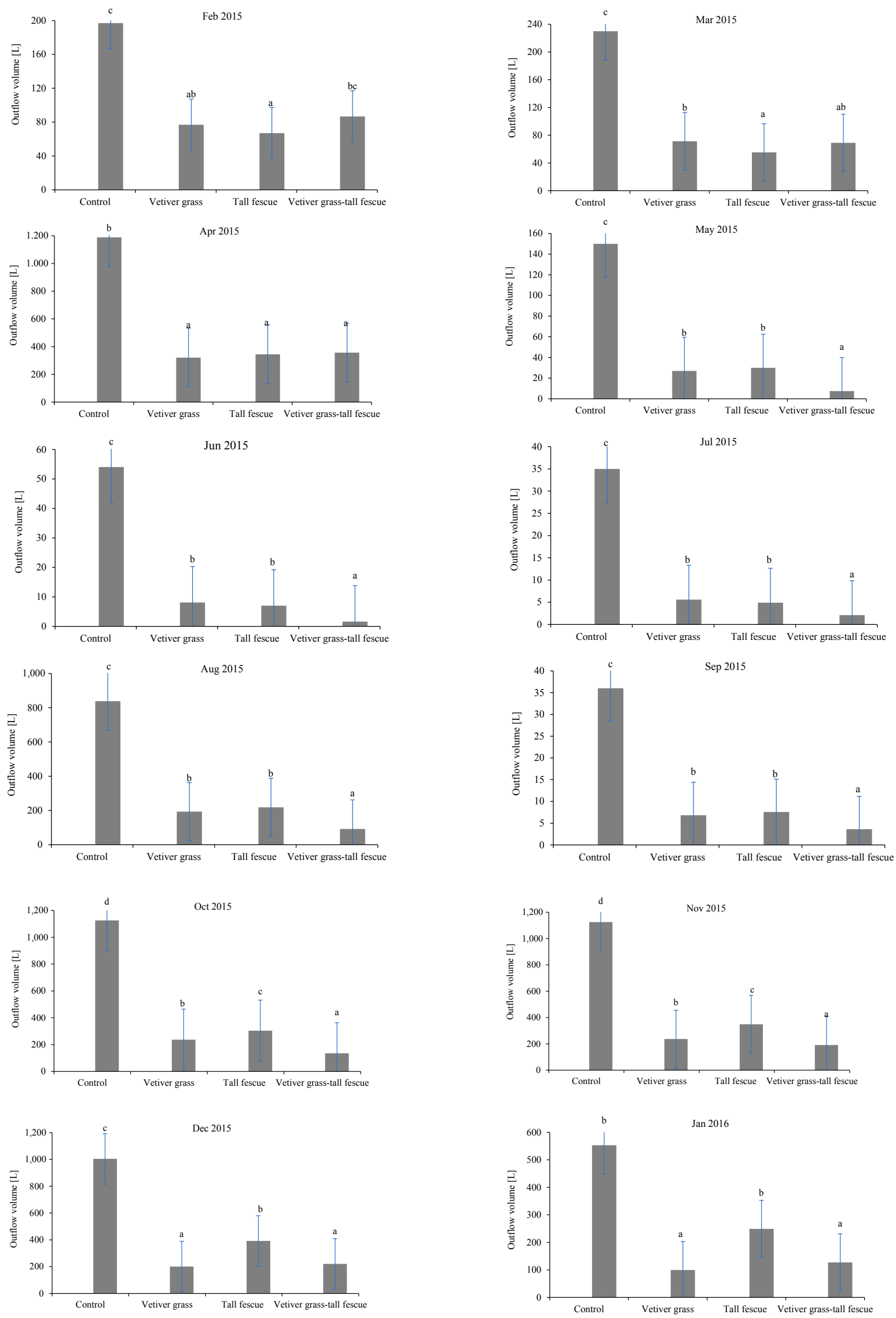

Figure 3. Variations of mean outflow volume in the four studied treatments during the experiment (Means followed by the same letter do not differ statistically) 


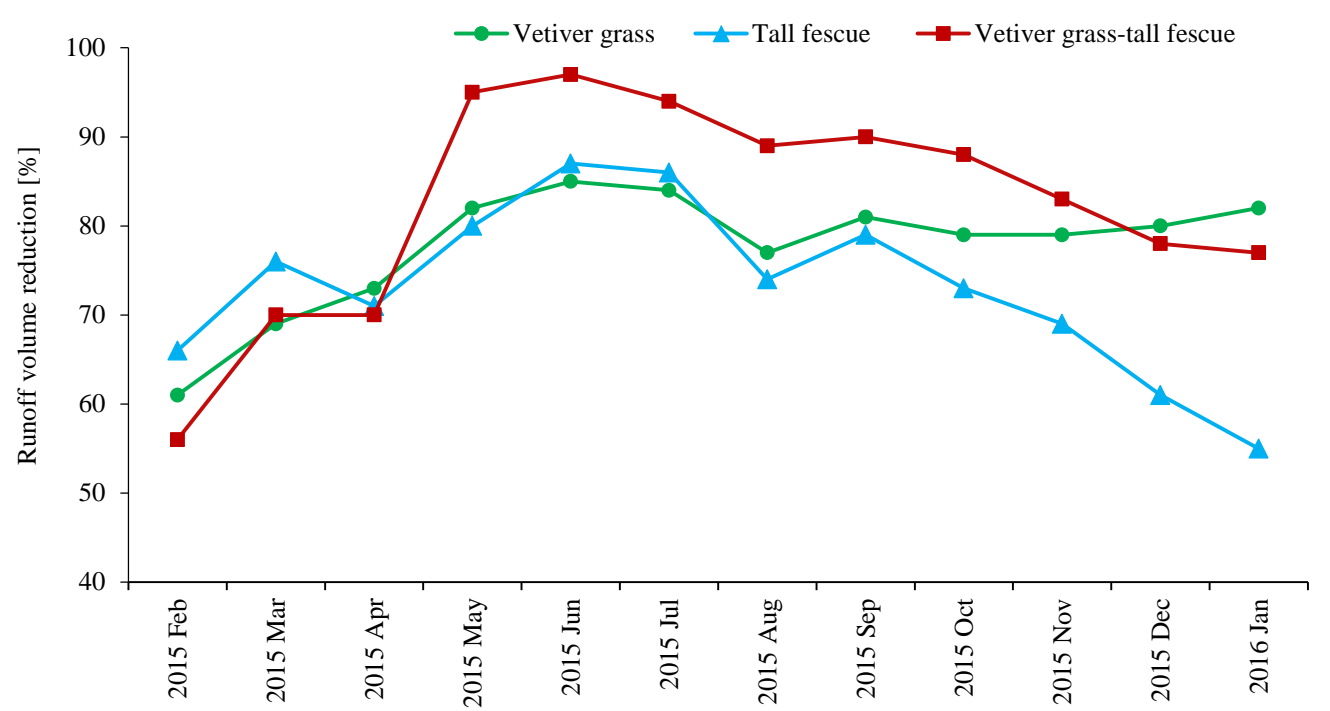

Figure 4. Variations of the efficiency of the studied vegetative buffer strips in runoff volume reduction during the experiment

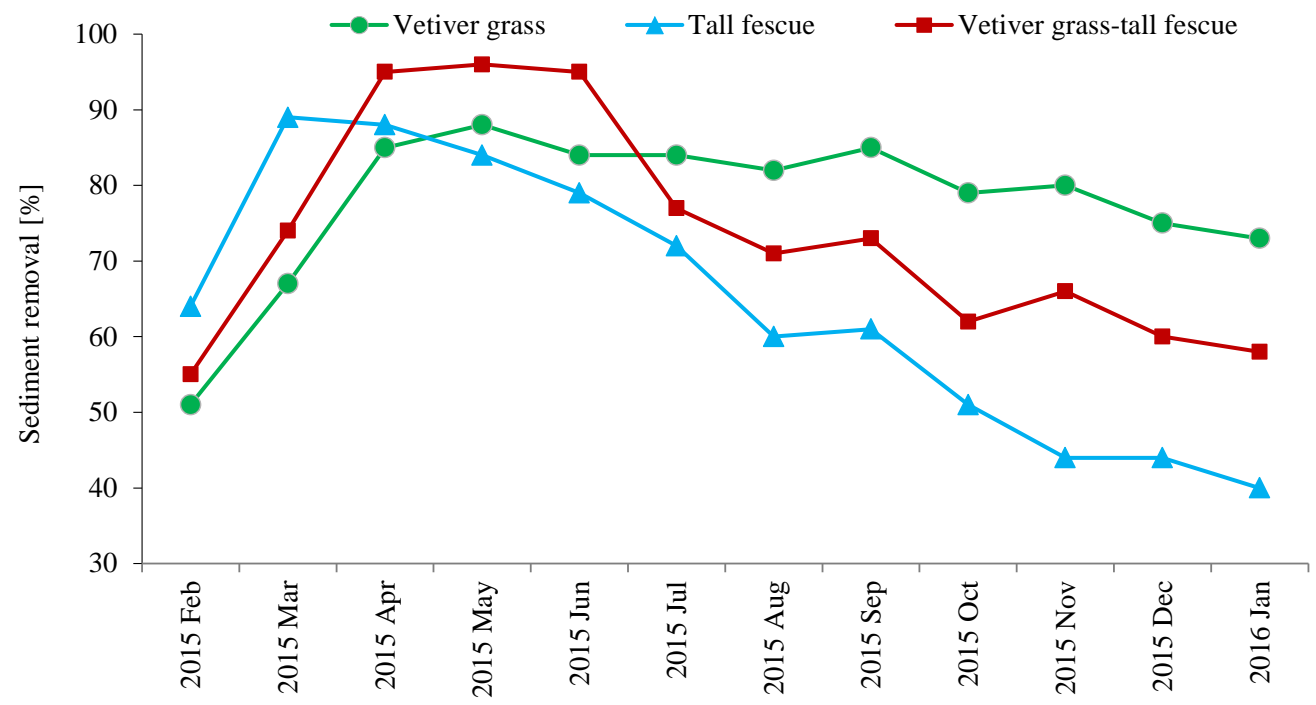

Figure 5. Variations of the efficiency of the studied vegetative buffer strips in sediment removal during the experiment

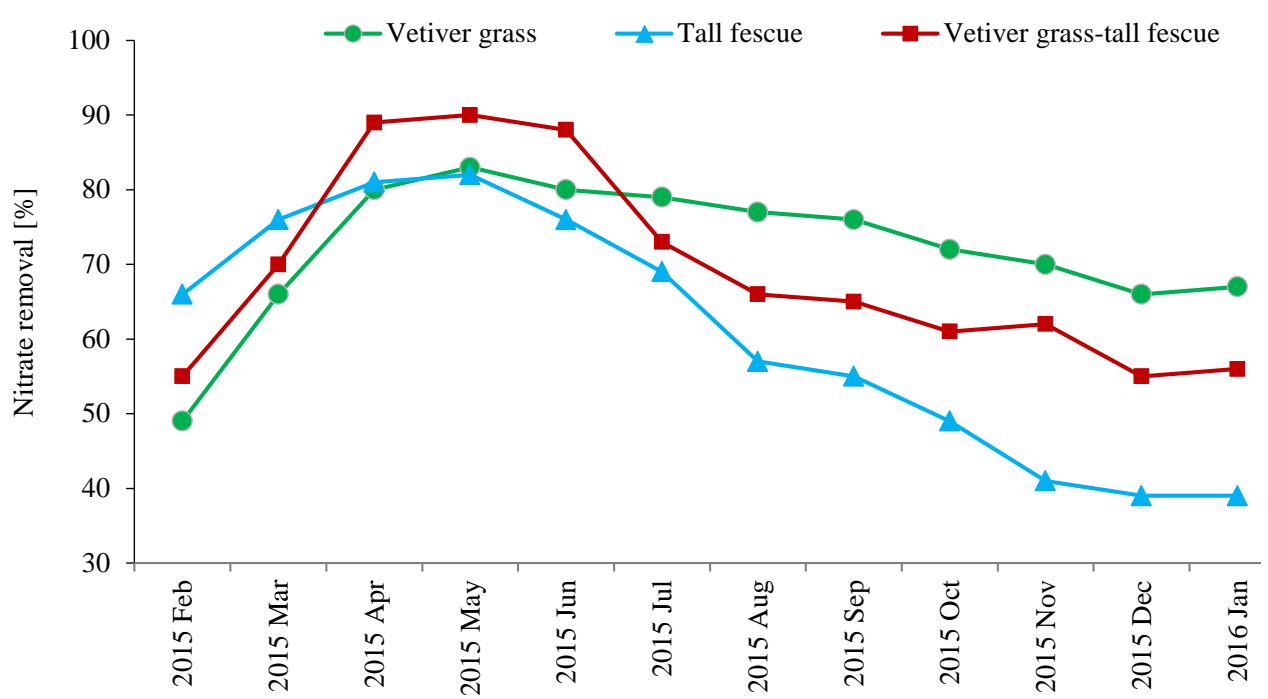

Figure 6. Variations of the efficiency of the studied vegetative buffer strips in nitrate removal during the experiment 
since the fourth month until the $10^{\text {th }}$ month of the experiment. Moreover, the best efficiency was obtained in the $11^{\text {th }}$ and $12^{\text {th }}$ months for the treatment of vetiver grass. As it is observed, the highest efficiency $(97 \%)$ was found for the treatment of vetiver grass-tall fescue in the fifth month.

\section{Sediment concentration}

After some fluctuations, the treatment of vetiver grass showed the minimum amount of sediment concentration with a significant difference $(P=0.01)$ compared to the other treatments since the sixth month until the end of the experiment (Table 4). The main reasons include the ability of vetiver grass for sediment removal and its compatibility with different climatic conditions, as well as the vulnerability of tall fescue.

As Figure 5 shows, the maximum efficiency in the first and second months was observed for the treatment of tall fescue; while the treatment of vetiver grass-tall fescue had more appropriate performance than the other treatments in the third, fourth and fifth months. Since the sixth month of the experiment, the treatment of vetiver grass showed the best efficiency of sediment removal until the end of the experiment. The highest efficiency (96\%) during the experiment period was also related to the treatment of vetiver grass-tall fescue in the fourth month.

\section{Nitrate}

According to Figure 6, the maximum efficiency $(90 \%)$ in nitrate removal was found in the fourth month of the experiment for the treatment of vetiver grass-tall fescue. But, the treatment of vetiver grass showed the best performance since the sixth month until the end of the experiment.

\section{Phosphate}

As the results indicate, the best function of phosphate removal was determined in the third month by the treatment of vetiver grass-tall fescue. Since the sixth month of the experiment, the highest efficiency was obtained by the treatment of vetiver grass until the end of the experiment (Figure 7).

\section{DISCUSSION}

According to the results (Figure 4), the treatment of tall fescue has had the maximum runoff reduction in the first and second months of the experiment which is consistent with Owino et al. (2006) and Yuan et al. (2009). Since the third month when the tall fescue and vetiver grass had their maximum vegetation cover, the treatment of vetiver grass-tall fescue showed the minimum outflow volume. The maximum efficiency of the buffer strips in qualitative

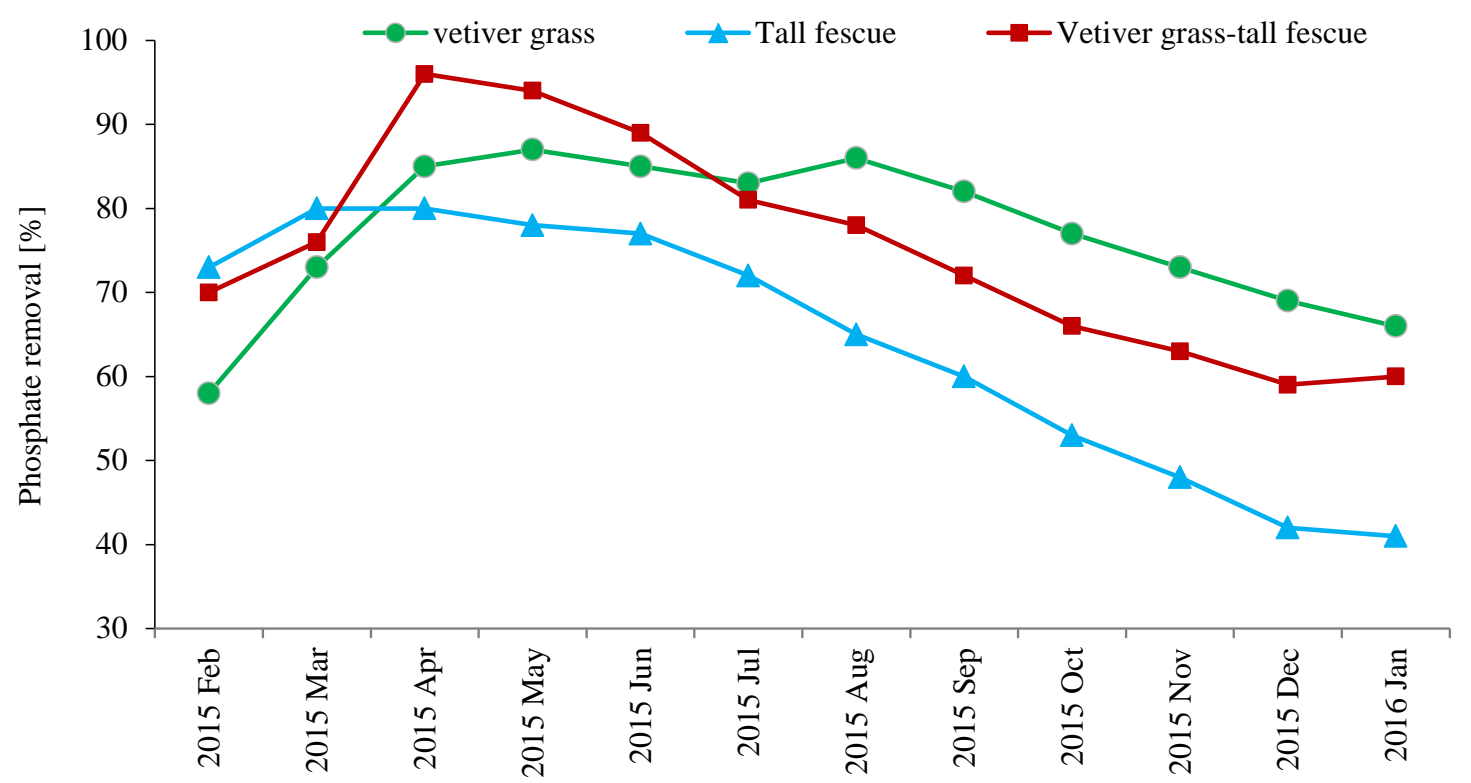

Figure 7. Variations of the efficiency of the studied vegetative buffer strips in phosphate removal during the experiment 
and quantitative control of the runoff occurs when the flow passes through the strips as a sheet (Hussein et al. 2007). So, the highest efficiency in the runoff volume reduction was found for the treatment of vetiver grass-tall fescue because the runoff reached to the vetiver grass strip as a sheet flow after passing through the tall fescue strip. Hence, the flow was not concentrated among the bushes of vetiver grass; so, the strip of vetiver grass could present its capability to increase soil permeability. Lee et al. (2003) also obtained the same result which explains the proper performance of the combined vegetative buffer strips to control runoff volume and pollutants. In the last two months of the experiment, the vegetation cover of tall fescue was reduced because of changing the climatic conditions as well as grazing over the time. Therefore, the efficiency of tall fescue strip dropped while the vegetative strip kept its high efficiency in runoff volume reduction because of strong root system, higher biomass as well as compatibility to various climatic conditions. This result is consistent with Mankin et al. (2007) and Golabi et al. (2005).

Investigating the results of sediment concentration (Figure 5) represented that, the combination of vetiver grass and tall fescue can give a high efficiency in sediment removal. But, when the vegetation cover of tall fescue reduced (since the sixth month), the treatment of vetiver grass showed the highest efficiency of sediment removal compared to the other treatments until the end of the experiment. The high performance of vetiver grass is due to high resistance in various seasons and climatic conditions as well as dormancy in cold season. So, vegetation cover reduction is prevented. The achieved results are consistent with Golabi et al. (2005), Pan \& Shanggun (2006) and Stutter et al. (2009).

By approaching the end of experiment, the mean concentration of sediment was higher than the early months of the experiment. This happening can be related to the sediment accumulation in the vegetative strips over time. Therefore, the vegetative buffer strips can play role as the source of sediment. Osborne \& Kovacic (1993), Bhattarai et al. (2009) and Stutter et al. (2009) also obtained the same result.

The results of nitrate and phosphate (Figure 6 and 7) also represent proper function for vetiver grass-tall fescue when the mentioned plants have their maximum growth and vegetation cover. While, the treat- ment of vetiver grass showed higher stability than the composed buffer strip for nitrate removal due to higher resistance against grazing and climatic condition changes. This result is consistent with Matteo et al. (2006) and Lee et al. (2003). The achieved results for nitrate and phosphate are almost same as the sediment; because, the nutrients are attached to the sediment particles and transferred (Barling 1994).

\section{CONCLUSIONS}

The plots with vetiver and tall fescue buffer strips both were able to reduce runoff, sediment, nitrate and phosphate concentrations as compared to the control. But, the vetiver grass was more effective than other treatments when the plants reached maturity. Also, tall fescue showed less effective than vetiver grass at reducing in runoff, pollutant transport and soil erosion. Because, the effectiveness of tall fescue sharply decreased after the second month since planting. Therefore, the appropriate effectiveness of vetiver grass-tall fescue treatment reduced after a short time. Hence, a more appropriate efficiency for water and soil conservation will be achieved if a plant species with a density and uniformity like the tall fescue being resistant and compatible to the climatic conditions of the considered region is used along with vetiver grass in the vegetative buffer strips. The results of this study showed that the vegetative buffer strips can also act as a source of nutrients and sediment. So, periodic plants cutting and dredging of buffer strips is recommended as an effective strategy to deal with this problem. In addition, doing researches on the width of the strips, the impact of length and shape of the sub/catchment above the strip, rainfall intensity and soil moisture on the efficiency of the vegetative buffer strips can be helpful to enhance the impact of these strips in the water and soil conservation in different watersheds.

\section{REFERENCES}

BARLING, R.D. 1994. Role of Buffer Strips in Management of Waterway Pollution: A Review. In Environmental Management, vol. 18, vol. 4, pp. 543-558.

BHATTARAI, R. - KALITA, P.K. - PATEL, M.K. 2009. Nutrient transport through vegetative filter strip with subsurface drainage. In Journal of Environmental Management, vol. 90, pp. 1868-1876. 
BORIN, M. - PASSONI, M. - THIENE, M. - TEMPESTA, T. 2010. Multiple functions of buffer strips in farming areas In European Journal of Agronomy, vol. 32, pp. 103-111.

BORINA, M. - VIANELLOA, M. - MORARIA, F. - ZANINBG. 2005. Effectiveness of buffer strips in removing pollutants in runoff from a cultivated field in North-East Italy. In Agriculture, Ecosystems and Environment, vol. 105, pp. 101-114.

CAMPO-BESCOS, M.A. - MUNOZ-CARPENA, R. - KIKER, G.A. - BODAH, B.W. - ULLMAN, J.L. 2015. Watering or buffering? Runoff and sediment pollution control from furrow irrigated fields in arid environments. In Agriculture, Ecosystems and Environment, vol. 205, pp. 90-101.

DABNEY, S.M. 2003. Erosion control, vegetative. In Encyclopaedia of Water Science. New York, USA: Marcel Dekker, Madison Ave, pp. 272-276.

DELGADO, A.N. - PERIAGO, E.L. - VIQUERIA, F.D. 1995 Vegetated filter strips for wastewater purification: a review. In Bioresource Technology, vol. 51, pp. 13-22.

DUCHEMIN, M. - HOGUE, R. 2009. Reduction in agricultural non-point source pollution in the first year following establishment of an integrated grass/tree filter strip system in southern Quebec (Canada). In Agriculture, Ecosystems and Environment, vol. 131, pp. 85-97.

GOLABI, M.H. - IYEKAR, C. - MINTON, D. - RAULERSON, C.L. - DRAKE, J.C. 2005. Watershed management to meet water quality standards by using the vetiver system in Southern Guam. In Austral Journal of Technology, vol. 9, pp. 63-70.

HAY, V. - PITTROFF, W. - TOOMAN, E.E. - MEYER, D. 2006. Effectiveness of vegetative filter strips in attenuating nutrient and sediment runoff from irrigated pastures. In Journal of Agricultural Science, vol. 144, pp. 349-360.

HUSSEIN, J. - YU, B. - GHADIRI, H. - ROSE, C. 2007. Prediction of surface flow hydrology and sediment retention upslope of a vetiver buffer strip. In Journal of Hydrology, vol. 338 , pp. $261-272$.

IRANIAN ASSOCIATION FOR VETIVER PROMOTUION. 2011. Vetiver system to prevent and treatment of chemical pollutions of water and soil. $1^{\text {st }}$ National Phytoremediation Conference, Kerman, Iran, 580 p. (In Persian)

KAVIAN, A. - AZMOODEH, A. - SOLAIMANI, K. 2014. Deforestation effects on soil properties, runoff and erosion in northern Iran. In Arabian Journal of Geosciences, vol. 7, no. 5, pp. 1941-1950.

KAVIAN, A. - HOSEINPOUR SABET, S. - SOLAIMANI, K. - JAFARI, B. 2017. Simulating the effects of land use changes on soil erosion using RUSLE model. In Geocarto International, vol. 32, no. 1, pp. 97-111.

KEESSTRA, S. - PEREIRA, P. - NOVARA, A. - BREVIK, E.C. - AZORIN-MOLINA, C. - PARRAS-ALCÁNTARA, L. - JORDÁN, A. - CERDÀ, A. 2016. Effects of soil management techniques on soil water erosion in apricot orchards. In Science of the Total Environment, vol. 551-552, pp. 357-366.

KELARESTAGHI, A.A. - AHMADI, H. - ESMAEILI ORI, A - GHODUSI, J. 2008. Comparison of runoff and sediment production in various agricultural land use treatments. In Iran-Watershed Management Science and Engineering, vol. 2 , no. 5, pp. 41-52.

LAMBRETCHS, T. - FRANCOIS, S. - LUTTS, S. - MUNOZ-CARPENA, R. - BIELDERS, C. 2014. Impact of plant growth and morphology and of sediment concentration on sediment retention efficiency of vegetative filter strips: Flume experiments and VFSMOD modeling. In Journal of Hydrology, vol. 511, pp. 800-810.

LEE, K.H. - ISENHART, T.M. - SCHULTZ, R.C. - MICKEL-
SON, K.S. 1999. Nutrient and sediment removal by switchgrass and cool-season filter strips in Central Iowa, USA. In Agroforestry Systems, vol. 44, pp. 121-132.

LEE, K.H. - ISENHART, T.M. - SCHULTZ, R.C. 2003. Sediment and nutrient removal in an established multi-species riparian buffer. In Journal of Soil and Water Conservation, vol. 58 , no. 1, pp. 1-8.

MANKIN, K.R. - DANIEL, M.N. - CHARLES, J.B. - STACY, L.H. - WAYNE, A.G. 2007. Grass-shrub riparian buffer removal of sediment, phosphorus, and nitrogen from simulated runoff. In Journal of the American Water Resources Association (JAWRA), vol. 43, no. 5, pp. 1108-1116.

MATTEO, M. - RANDHIR, T. - BLONIARZ, D. 2006. Watershed-scale impacts of forest buffers on water quality and runoff in urbanizing environment. In Journal of Water Resources Planning and Management, vol. 132, no. 3, pp. $144-152$.

MILAN, M. - FERRERO, A. - LETEY, M. - DE PALO, F. VIDOTTO, F. 2014. Effect of buffer strips and soil texture on runoff losses of flufenacet and isoxaflutole from maize fields. In Journal of Environmental Science and Health, Part B, vol. 48, pp. 1021-1033.

MOHAMMADI, M.A. - KAVIAN, A. 2015. Effects of rainfall patterns on runoff and soil erosion in field plots. In International Soil and Water Conservation Research, vol. 3, no. 4, pp. 273-281.

MORGAN, R.P.C. 1995. Soil erosion and conservation, 2nd edition. Longman, Addison, pp. 175-176.

NORRIS, V. 1993. The use of buffer zones to protect water quality: A review. In Water Resources Management, vol. 7, pp. 257-272.

OSBORNE, L.L. - KOVACIC, D.A. 1993. Riparian vegetated buffer strips in water-quality restoration and stream management. In Freshmler Biology, vol. 29, pp. 243-258.

OWINO, J.O. - OWIDO, S.F.O. - CHEMELIL, M.C. 2006. Nutrients in runoff from a clay loam soil protected by narrow grass strips. In Soil \& Tillage Research, vol. 88, pp. $116-122$.

PAN, CH. - SHANGGUN, Z. 2006. Runoff hydraulic characteristics and sediment generation in sloped grassplots under simulated rainfall conditions. In Journal of Hydrology, vol. 331, pp. 178-185.

PATTY, L. - REAL, B. - GRIL, J. 1997. The use of grassed buffer strips to remove pesticides, nitrate and soluble phosphorus compounds from runoff water. In Pest Management Science, vol. 49, pp. 243-251.

RODROGO-COMINO, J. - DAVIS, J. - KEESSTRA, S.D. CERDA, A. 2018. Updated measurements in vineyards improves accuracy of soil erosion rates. In Agronomy Journal, vol. 110 , no. 1, pp. 411-417.

SADEGHI RAVESH, M.H. 2011. Comparison of human thermal comfort amount in arid and humid climates (Case study: Yazd and Sari cities). In Arid Biom Scientific and Research Journal, vol. 1, no. 2, pp. 50-61.

SALEH, I. - KAVIAN, A. - HABIBNEJAD, M. - JAFARIAN, Z. 2017. The efficiency of vegetative buffer strips in runoff quality and quantity control. In International Journal of Environmental Science and Technology, pp. 1-10. DOI: 10.1007/s13762-017-1411-2. Article in Press.

SOOSHTARIAN, S. - TEHRANIFAR, A. 2011. Introducing the vetiver grass. Iranian Agricultural Science Publisher, $170 \mathrm{p}$.

SPSS INK. 2009. PASW Statistics for OSX, Version 18.0. SPSS Inc., Chicago.

STUTTER, M. - LANGAN, S. - LUMSDON, A. 2009. Vegetated buffer strips can lead to increased release of phosphorus to waters: A biogeochemical assessment of the mech- 
anisms. In Environment Science Technology, vol. 43, pp. $1858-1863$.

WAKIDA, F.T. - MARTINEZ-HUATO, S. - GARCIA-FLORES, E. - PINON-COLIN, T.D.G. ESPINOZA-GOMEZ, H. - AMES-LOPEZ, A. 2014. Pollutant association with suspended solids in stormwater in Tijuana, Mexico. In International Journal of Environmental Science and Technology, vol. 11, no. 2, pp. 319-326.
YUAN, Y. - BINGNER, R.L. - LOCKE, M.A. 2009. A Review of effectiveness of vegetative buffers on sediment trapping in agricultural areas. In Journal of Ecohydrology, vol. 2, pp. 321-336.

Received: October 2, 2017 